\title{
KARAKTERISTIK IKAN ASIN KAMBING-KAMBING (Canthidermis maculata) DENGAN PENGGARAMAN KERING
}

\author{
Akbardiansyah*, Desniar, Uju \\ Departemen Teknologi Hasil Perairan, Fakultas Perikanan dan Ilmu Kelautan, \\ Institut Pertanian Bogor, kampus IPB Dramaga, Jalan Agatis, Bogor, Jawa Barat 16680 \\ Telepon (0251) 8622909-8622907, Faks (0251) 8622907 \\ *Korespondesi:akbar.diansyah@ymail.com \\ Diterima: 7 Juni 2018/Disetujui: 24 Agustus 2018
}

Cara sitasi : Akbardiansyah, Desniar, Uju. 2018. Karakteristik ikan asin kambing-kambing (Canthidermis maculata) dengan penggaraman kering. Jurnal Pengolahan Hasil Perikanan Indonesia. 21(2): 345-355.

\begin{abstract}
Abstrak
Ikan kambing-kambing (Canthidermis maculata) merupakan ikan demersal yang potensial. Salah satu produk olahan dari ikan kambing-kambing adalah ikan asin. Tujuan dari penelitian ini adalah menentukan pengaruh konsentrasi garam dan lama penggaraman terhadap karakteristik ikan asin yang dihasilkan. Penelitian dilakukan dalam dua tahap, tahap pertama adalah preparasi bahan baku tahap kedua pembuatan ikan asin menggunakan metode penggaraman kering dengan konsentrasi garam 5\%, 10\% dan 15\% dengan lama penggaraman $12 \mathrm{jam}$ dan $24 \mathrm{jam}$. Analisis data pada pruduk ikan asin kering menggunakan rancangan acak lengkap faktorial (RALF) dengan dua kali ulangan Ikan kambing-kambing yang digunakan sebagai bahan baku dengan nilai organoleptik 7-9. Komposisi kimia dan total mikroba ikan kambing-kambing dengan kadar air yaitu $77,00 \pm 0,32 \%$ abu $0,96 \pm 0,01 \%$ lemak $0,59 \pm 0,11 \%$ protein $20,58 \pm 0,16 \%$ karbohidrat $0,89 \pm 0,05 \% \mathrm{pH} 6,46 \pm 0,03 \%$, dan total mikroba $6,13 \times 10^{3}$. Konsentrasi garam dan lama penggaraman berpangaruh nyata terhadap karakteristik ikan asin yang meliputi kadar garam, kadar air dan total mikroba, konsentrasi garam 15\% dengan lama penggaraman 24 jam merupakan perlakuan pruduk ikan asin terbaik.
\end{abstract}

Kata kunci: analisis komposisi kimia, analisis mikroba, ikan asin, total mikroba

\section{Characteristic of Dry Salted Spotted Oceanic Triggerfish (Canthidermis maculata)}

\begin{abstract}
Spotted oceanic triggerfish (Canthidermismaculata) is a potential demersal fish for consumption. One of the processed products of Spotted oceanic triggerfish is salted fish. Our goals in this research were to determine the effect of salt concetration and salting time on the characteristics of salted fish produced. The research was carried out in two stages, the first stage was the preparation of raw materials and the second stage was the production of salted fish using salt method with a salt concentration of 5\%, 10\%, dan $15 \%$ (w/w) for 12 and 24 hours of salting. Data analysis used factorial completely randomized design (RALF) with two replications. Spotted oceanic triggerfish used as raw material had organoleptic value 7-9. Fish meat had $\mathrm{pH} 6.46 \pm 0.03$ and contained $77.00 \pm 0.32 \%$ of moisture, $0.96 \pm 0.01 \%$ of ash, $0.59 \pm 0.11 \%$ of fat, is $20.58 \pm 0.16 \%$ of protein, $0.89 \pm 0.05 \%$ of carbohydrate, $6.13 \times 10^{3}$ of total microbial. The salt concentration and salting time had significant effect on the salted fish characteristics such as salt, water, and microbes content. Salting at $15 \%$ for 24 hour was the best treatment.
\end{abstract}

Keywords : chemical composition analysis, microbial analysis, salted fish, total microbial 


\section{PENDAHULUAN}

Ikan kambing-kambing (Canthidermis maculata) merupakan salah satu ikan demersal yang potensial. Potensi perikanan demersal Provinsi Aceh di Selat Malaka pada tahun 2011 mencapai 151.3 ton (Perikanan Tangkap Provinsi Aceh 2015). Potensi ini harus dimanfaatkan dengan maksimal mengingat kebutuhan konsumsi ikan semakin meningkat setiap tahunnya. Pemanfaatan ikan kambing-kambing sudah banyak dilakukan oleh Usaha Mikro Kecil Menengah (UMKM), baik untuk bahan baku breaded product maupun produk tradisional, khususnya ikan asin. Ikan asin sangat digemari dan sudah lama dikenal dikalangan masyakat. Kebutuhan ikan asin masih sangat tinggi, hal ini ditunjukkan dengan jumlah impor ikan kering (asin) sepanjang tahun 2017 mencapai 16.329,33 kg (BKIPM 2017).

Permasalahan lain pada produk ikan asin di pasaran adalah mutu yang cenderung rendah. Febrinawati (2017) melaporkan bahwa ikan asin kepala batu di Kabupaten Tulang Bawang memiliki cemaran mikroba berdasarkan total plate count (TPC) melebihi ambang batas yang ditetapkan dalam SNI 8273:2016. Riski et al. (2017) melaporkan bahwa pada sentral pengolahan ikan asin daerah Leupung Aceh Besar sebanyak 50\% sampel yang diuji melebihi ambang batas SNI 8273:2016 untuk kadar air dan cemaran mikroba. Ackbarali dan Maharaj (2014) melaporkan bahwa tingkat penerimaan suatu produk oleh konsumen merupakan salah satu faktor penting dalam memproduksi suatu produk yang bermutu.

Pengolah ikan asin di Provinsi Aceh cenderung menggunakan konsentrasi garam yang tinggi. Hal ini dilakukan untuk meningkatkan berat ikan asin kering dan meningkatkan daya simpan walaupun kadar air yang masih tergolong tinggi. Metode ini menyebabkan kadar garam dalam produk menjadi tinggi dan melebihi SNI 8273:2016, sehingga dapat menurunkan tingkat penerimaan konsumen. Lama penggaraman juga dapat mempengaruhi komposisi kimia dan penilaian organoleptik produk ikan asin (Rochima 2005; Riansyah et al. 2013). Penelitian mengenai ikan asin sudah dilaporkan oleh beberapa peneliti. Tumbelaka et al. (2013) melaporkan bahwa penggunaan konsentrasi garam 15\% selama 7 jam penggaraman merupakan kombinasi yang tepat untuk mendapatkan ikan bandeng asin kering terbaik, sedangkan Tahitu (2014) melaporkan bahwa konsentrasi garam dan waktu perendaman yang terbaik adalah 6 jam pada konsentrasi garam 40\%. Ikan asin telah di konversi menjadi nugget dengan mencampurkan ampas tahu dan beberapa jenis binder (Hardoko et al. 2018). namun ikan asin yang sesuai dengan standar mutu masih terbatas .

Standar mutu ikan asin kering (SNI 8273:2016), antara lain: kadar air maksimum $40 \%$, kadar garam maksimum $12-20 \%$, dan ALT maksimum $1 \times 10^{5}$ koloni/g, kadar abu tidak larut asam 0,3\% (BSN 2016). Penelitian ini diharapkan dapat meningkat penerimaan konsumen dan ikan asin yang dihasilkan sesuai dengan SNI. Penelitian ini bertujuan menentukan pengaruh konsentrasi garam dan waktu penggaraman terhadap karakteristik ikan asin yang dihasilkan.

\section{BAHAN DAN METODE Bahan dan Alat}

Bahan utama yang digunakan dalam penelitian ini adalah ikan kambing-kambing (Canthidermis maculata), yang diperoleh dari pelabuhan Lampulo Banda Aceh Provinsi Aceh. Bahan lain yang digunakan antara lain es, garam beryodium, $\mathrm{K}_{2} \mathrm{SO}_{4}$ (Merck, Jerman) $\mathrm{CuSO}_{4}$ (Merck, Jerman), $\mathrm{H}_{3} \mathrm{BO}_{3}$ (Merck, Jerman), $\mathrm{NaCl}$ (Merck, Jerman), $\mathrm{K}_{2} \mathrm{C}_{\mathrm{r}} \mathrm{O}_{4}$ (Merck, Jerman), $\mathrm{AgNO}_{3}$ (Merck, Jerman).

Peralatan yang digunakan dalam penelitian ini antara lain timbangan analitik (Chyo Jl-180) dan timbangan digital (Quattro Mac-W, Indonesia), inkubator (Yomato 15900, Jepang), oven (Ehret TK/L, Indonesia) $\mathrm{a}_{\mathrm{w}}$ meter (Rotronic-Hygrolab), pH meter (Lamotte pHPlus Direct), pisau, baskom, parapara penjemuran dan alat-alat gelas (pyrex, Indonesia) 


\section{Metode Penelitian \\ Preparasi bahan baku}

Ikan kambing-kambing sebelum digunakan untuk bahan baku dilakukan pengujian dan analsisis yang meliputi uji organoleptik, analisis proksimat, total mikroba, dan $\mathrm{pH}$. Ikan kambing-kambing disiangi dengan cara mengeluarkan insang dan isi perutya, kemudian ikan dicuci sampai bersih. Ikan dikuliti dan dilakukan pemisahan daging dari tulang. Daging yang diperoleh di potong-potong dengan dimensi rata-rata $(5 \mathrm{x}$ $2 \times 2) \mathrm{cm}$. Daging ikan dicuci, dan setrusnya dilakukan penirisan dalam keranjang dan penegringan. Setelah kering, daging ikan dipotong-potong dan ditimbang ditimbang.

\section{Pembuatan ikan asin}

Metode pembutan ikan asin mengacu terhadap metode tradisional pembuatan ikan asin yang dilakukan oleh masyarakat Aceh. Potongan daging ikan ditambahkan garam dengan garam 5\%, 10\%, dan 15\% (b/b). Metode penggaraman yang digunakan adalah penggaraman kering. Ikan yang telah dilemuri garam dalam wadah secara merata kemudian dibiarkan pada suhu ruang selama 12 jam atau 24 jam. Ptongan daging ikan dicuci kembali dan dijemur diatas para-para selama tiga hari dengan periode pengeringan 7 jam per hari. Ikan asin di analisis kadar garam, kadar air, total mikroba dan uji organoleptik.

\section{Uji organolpetik ikan segar dan uji sensori ikan asin}

Pengujian organoleptik dilakukan untuk menentukan kesegaran bahan baku yang digunakan. Uji organoleptik bahan baku berdasarkan SNI 01-2729.1-2006 tentang penilaian ikan segar. Parameter yang diuji meliputi kenampakan mata, insang, lendir permukaan badan, daging (warna dan kenampakan), bau dan tekstur. Kisaran nilai organoleptik bahan baku yang disediakan adalah 1-9.

Pengujian sensori ikan asin mengacu pada SNI 8273:2016. Parameter penilaian i meliputi kenampakan, bau, rasa, tekstur dan jamur dengan kisaran nilai yang disediakan 5-9, sedangkan kisaran nilai untuk keberadaan jamur adalah 1 (ada) dan 9 (tidak ada).

\section{Analisis proksimat}

Analisis proksimat yang dilakukan mengacu pada metode AOAC (2005). Analisis proksimat dilakukan terhadap bahan baku dan produk (ikan asin) meliputi analisis kadar air, kadar abu, kadar protein dan kadar lemak.

\section{Derajat keasaman $(\mathrm{pH})$}

Sampel sebayak 0,2 g ditimbangkan dan didispersikan kedalam $20 \mathrm{~mL}$ akuades pada suhu $80^{\circ} \mathrm{C}$, sampel dihomogenkan dengan magneticstirrer. Sampel diukur derajat keasamannya pada suhu kamar dengan $\mathrm{pH}$ meter.

\section{Analisis total mikroba}

Prinsip kerja dari analisis total mikroba mengacu pada metode BSN (2006). Perhitungan jumlah koloni bakteri yang ada di dalam sampel dengan pengenceran sesuai keperluan dan dilakukan secara duplo. Pengerjaan seluruhnya dilakukan secara aseptik untuk mencegah kontaminasi yang tidak diinginkan dan pengamatan secara duplo dapat meningkatkan ketelitian. Jumlah koloni bakteri yang dapat dihitung dengan cawan petri yang mempunyai koloni bakteri berkisar antara 23-250 koloni. Cawan petri, tabung reaksi dan pipet sebelum digunakan disterilkan terlebih dahulu dalam oven pada suhu $180^{\circ} \mathrm{C}$ selama 2 jam. Media disterilkan dalam autoklaf pada suhu $121^{\circ} \mathrm{C}$ selama 15 menit dengan tekanan 1 atm. Suhu media dipertahankan pada suhu $45-55^{\circ} \mathrm{C}$ dalam penangas air. Pembuatan larutan pengencer dilakukan dengan cara melarutkan $8,5 \mathrm{~g} \mathrm{NaCl}$ dalam $1 \mathrm{~L}$ akuades yang kemudian disterilkan dalam autoklaf pada suhu $121^{\circ} \mathrm{C}$ selama 15 menit.

Sampel sebanyak $10 \mathrm{~g}$ dihaluskan kemudian dilarutkan ke dalam larutan pengencer steril yang telah berisi dengan volume mencapai $100 \mathrm{~mL}$ sehingga didapatkan pengenceran $10^{1}$. Satu $\mathrm{mL}$ Larutan tersebut diambil dengan pipet, kemudian dimasukkan ke dalam tabung reaksi yang telah berisi $9 \mathrm{~mL}$ larutan pengencer steril untuk memperoleh pengenceran $10^{-2}$. Seterusnya sampai didapat pengenceran $10^{-5}$. Tahapan berikutnya pengenceran tersebut diambil dengan menggunakan pipet sebanyak $1 \mathrm{~mL}$ 
dimasukkan ke dalam cawan petri yang sudah disterilkan. Pengenceran dilakukan secara duplo, setiap cawan digerakkan secara melingkar di atas meja agar media NA merata, setalah NA membeku, cawan petri diinkubasi dalam inkubator selama 48 jam pada suhu $30^{\circ} \mathrm{C}$, cawan petri tersebut diletakkan secara terbalik dalam inkubator. Jumlah koloni bakteri yang dihitung adalah cawan petri yang mempunyai koloni bakteri antara 25-250 koloni dengan rumus perhitungan sebagai berikut:

$$
\text { Rumus : } N=+\frac{(\Sigma \mathrm{c})}{[(1 \times \mathrm{xn} 1)+(0.1 \mathrm{xn} 2)] \mathrm{x}(\mathrm{d})}
$$

Keterangan :

$$
\begin{aligned}
\mathrm{N}= & \text { jumlah koloni produk dinyatakan } \\
& \text { dalam koloni per } \mathrm{g} \\
\boldsymbol{\Sigma} \mathrm{C}= & \text { jumlah cawan pada semua cawan } \\
& \text { yang dihitung } \\
\mathrm{n} 1= & \text { jumlah cawan pada pengencer pertama } \\
& \text { yang dihitung } \\
\mathrm{n} 2= & \text { jumlah cawan pada pengenceran kedua } \\
& \text { yang dihitung } \\
\mathrm{d} \quad= & \text { pengenceran pertama yang digunakan }
\end{aligned}
$$

\section{Analisis kadar garam}

Penentuan kadar garam dilakukan dengan menggunakan metode Mohr atau titrasi ion korida dengan perak (AOAC 2005). Sampel (5 g) dimasukkan kedalam cawan porselen untuk dilakukan pengabuan dengan cara dipanaskan dalam tanur pada suhu $500^{\circ} \mathrm{C}$ selama 6 jam. Cawan porselen ditambahkan akuades, larutan abu yang terbentuk dimasukkan dalam labu takar 100 $\mathrm{mL}$. Akuades ditambahkan sampai tanda tera. Abu terlarut kemudian disaring dengan menggunakan kertas saring. Sebanyak 10 $\mathrm{mL}$ filtrat dimasukkan ke dalam erlenmeyer $250 \mathrm{~mL}$, lalu ditambahkan 5 tetes indikator $\mathrm{K} 2 \mathrm{CrO} 45 \%$ dan titrasi menggunakan $\mathrm{AgNO}_{3}$ $0,1 \mathrm{~N}$ sampai terbentuk warna merah bata atau jingga.

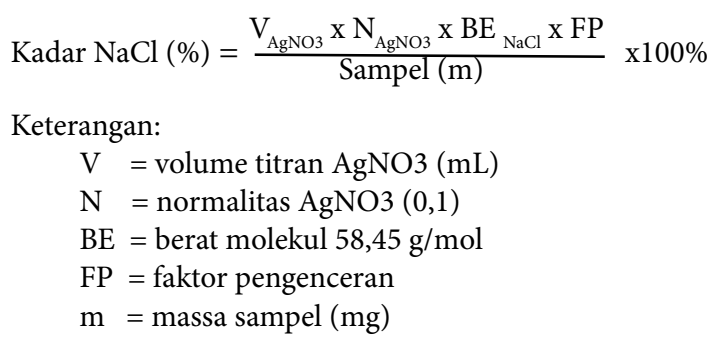

\section{ANALISIS DATA}

Rancangan percobaan yang digunakan pada proses pembuatan ikan asin adalah Rancangan Acak Lengkap Faktorial (RALF). Faktor variabel yang dianalisis konsentrasi garam dan waktu penggaraman, jika beda nyata antara taraf perlakuan maka dilanjutkan degan uji Duncan s Multiple Range Test (DTRT) pada taraf kepercayaan 95\%. Model Rancangan Acak Lengkap Faktorial mengacu pada Steel dan Torrie (1993).

$$
\text { Yijk }=\mu+\tau i+\beta j+(\tau \beta)+\varepsilon i j k
$$

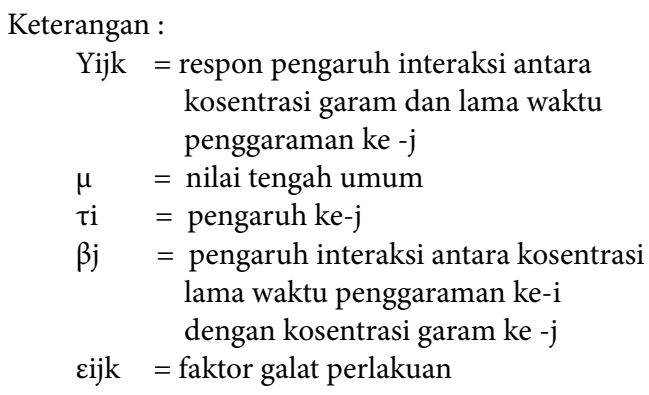

\section{HASIL DAN PEMBAHASAN Karakteristik Sensori Ikan Kambing- kambing (C. maculata)}

Hasil uji sensori ikan kambing-kambing dari semua parameter penilaian sensori ikan segar menunjukkan nilai sensori yang memenuhi standar kualitas ikan segar dengan nilai sensori diatas 7 (Gambar 1). Hal ini menunjukkan bahwa kualitas ikan kambingkambing yang digunakan dalam penelitian ini masih dalam kondisi segar. Standar ikan segar, berada pada rentang nilai rerata uji sensori pada spesifikasi kenampakan mata, insang, lendir permukaan badan, daging (wana dan kenampakan) bau dan tekstur ikan yang digolongkan segar berkisar pada 7-9 (BSN 2006).

Kenampakan mata pada uji sensori dengan nilai rerata 8 spesifikasi cerah, bola mata rata, kornea jernih. Insang dengan nilai rerata 8 (warna merah kurang cemerlang, tanpa lendir), sedangkan nilai uji sensori lendir permukaan badan dengan nilai rerata 8 (lapisan lendir jernih, transparan, cerah, belum ada perubahan warna), nilai uji sensori daging (warna dan kenampakan) diperoleh rerata 8 dengan spesifikasi sayatan daging cemerlang spesifik jenis, tidak ada pemerahan sepanjang tulang belakang, dinding perut 


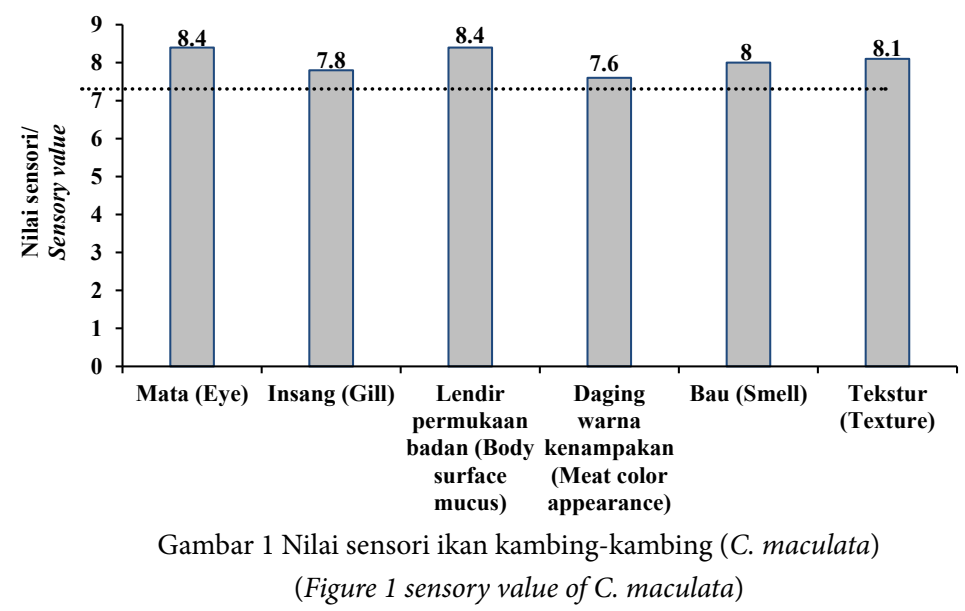

utuh. Uji sensori bau didapatkan rerata nilai 8 (segar, spesifik jenis), dan tekstur didapatkan nilai rerata 8 dengan spesifikasi agak padat, elastis bila ditekan dengan jari, sulit menyobek daging dari tulang belakang.

Tingkat kesegaran ikan merupakan salah-satu syarat mutu utama untuk dijadikan bahan baku dalam pengolahan selanjutnya. Perubahan mutu ikan dimulai saat ikan ditangkap dan terus berlanjut seiring perubahan komposisi kimia dan fisik pada ikan. Perubahan kimia dan fisik pada ikan dipengaruhi oleh beberapa faktor, salah satunya adalah cara penanganan yang baik yang melibatkan penerapan sistem rantai dingin. Menurut Junianto (2003) proses perubahan komposisi kimia dan fisik yang berdampak pada mutu organoleptik dimulai setelah ikan mati, dengan proses perubahan dimulai dari tahap pre rigor, rigor mortis dan post rigor. Faktor yang mempengaruhi kemunduran mutu ikan secara internal seperti jenis ikan, umur dan ukuran ikan, komposisi kimia, kondisi fisik, karakteristik kulit serta bentuk tubuh. Selain faktor internal, faktor eksternal juga mempengaruhi tingkat kesegaran ikan seperti pengaruh alat tangkap, penanganan pasca panen, musim tangkap, wilayah penangkapan dan suhu air saat ikan ditangkap (Irianto 2014).

\section{Komposisi Kimia dan Total Mikroba Ikan Kambing-kambing (C. maculata)}

Analisis komposisi kimia merupakan metode yang digunakan untuk mengukur kandungan air, abu, lemak, protein dan karbohidrat dalam bahan pangan. Hasil komposisi kimia pada ikan kambing-kambing dapat dilihat pada Tabel 1.

Protein daging ikan kambing-kambing, merupakan komponen penyusun terbesar setelah air yaitu $20,58 \pm 0,16 \%$. Daging ikan kambing-kambing lebih tinggi dari kadar protein L. latjanus dan Grouper. Njinkoue et al. (2016) melaporkan bahwa ikan dikategorikan berprotein tinggi apabila memiliki kandungan protein lebih dari $15 \%$. Abraham-Olukayode et al. (2012) melaporkan bahwa semakin tinggi persentase proteinnya maka semakin baik ikan tersebut untuk dikonsumsi.

Hasil kadar lemak pada ikan kambingkambing adalah $0,59 \pm 0,11 \%$. Kandungan lemak daging ikan kambing-kambing pada penelitian ini tergolong rendah. Venugoval (2008) melaporkan bahwa ikan berlemak rendah memiliki kandungan lemak kurang dari $3 \%$, berlemak sedang memiliki kadar lemak 3-5\%, berlemak tinggi memiliki kadar lemak lebih dari 7\%. Persentase kadar lemak daging ikan kambing-kambing pada penelitian ini lebih tinggi jika dibandingkan kandungan lemak ikan karang spesies $L$. lutjanus (Kumar et al. 2014) dan ikan karang spesies Grouper (Younis et al. 2011).

Kadar abu ikan kambing-kambing lebih rendah jika dibandingkan dengan kadar abu spesies ikan karang L. lutjanus (Kumar et al. 2014). Kandungan bahan organik dan air di dalam bahan pangan mencapai $96 \%$, sedangkan sisanya sebanyak $4 \%$ merupakan unsur-unsur mineral (anorganik), kadar 
Tabel 1 Komposisi kimia dan total mikroba ikan kambing-kambing (Table 1 Chemical composition and total microbial C. maculata)

\begin{tabular}{lccc}
\hline \multicolumn{1}{c}{ Parameter/Parameter } & $\begin{array}{c}\text { Ikan kambing- } \\
\text { kambing/ } \\
\text { C. maculata }\end{array}$ & $\begin{array}{c}\text { Ikan Groupera/ } \\
\text { Grouper }\end{array}$ & $\begin{array}{c}\text { Ikan Latjanus- } \\
\text { latjunus } / \text { L. latjanus }\end{array}$ \\
\hline Kadar protein/ Protein content (\%) & $20.58 \pm 0.16$ & $18.60 \pm 0.24$ & $15.67 \pm 0.11$ \\
Kadar lemak/ Lipids content (\%) & $0.59 \pm 0.11$ & $0.43 \pm 0.09$ & $0.24 \pm 0.02$ \\
Kadar abu/ Ash content (\%) & $0.96 \pm 0.01$ & $1.07 \pm 0.04$ & $1.54 \pm 0.16$ \\
Kadar air/ Moisture content (\%) & $77.00 \pm 0.32$ & $78.87 \pm 0.48$ & $76.29 \pm 1.44$ \\
pH/ pH & $6.46 \pm 0.03$ & - & - \\
Total mikroba/Total mikrobial & $6.13 \times 10^{3} \pm 0.00$ & - & - \\
\hline
\end{tabular}

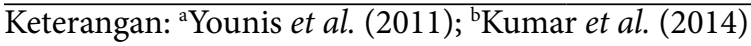

abu merupakan campuran dari komponen anorganik atau mineral yang terdapat dalam suatu bahan pangan yang tidak terbakar pada proses pembakaran bahan organik (Winarno 2008).

Persentase nilai kadar air ikan kambingkambing dalam penelitian ini lebih rendah jika dibandingkan dengan kadar air yang terdapat dalam daging jenis ikan karang lainnya. Ikan karang jenis Grouper memiliki kadar air $78,87 \pm 0,48 \%$ (Younis et al. 2011), sedangkan menurut Kumar et al. (2014) spesies ikan karang Lutjanus lutjanus yaitu 76,29 $\pm 1,44 \%$. Kadar air merupakan air bebas yang hanya terikat secara fisik dalam jaringan matriks bahan seperti membran dan kapiler (Winarno 2008). Kadar air juga merupakan indikator yang baik untuk menentukan jumlah relatif energi, protein dan lemak ikan berkadar air rendah cenderung memiliki kadar lemak dan protein yang relatif tinggi (Dempson et al. 2004).

Perbedaan komposisi proksimat dipengaruhi oleh dua faktor, yaitu faktor eksogenus dan endogenus. Alemu et al. (2013) melaporkan bahwa faktor eksogenus utama yang mempengaruhi komposisi proksimat pada ikan adalah pakan, sedangkan faktor endogenusnya meliputi ukuran, umur, jenis kelamin dan tingkat kematangan gonad (TKG). Nakamura et al. (2007); Roy et al. (2010) melaporkan bahwa komposisi proksimat suatu ikan juga dipengaruhi oleh letak bagian tubuh pada ikan, bagian perut memiliki kandungan lemak lebih tinggi dan protein lebih rendah dibandingkan dengan bagian dorsal.
Pengukuran $\mathrm{pH}$ didasarkan pada konsentrasi ion hidrogen pada suatu medium atau pelarut. Hasil uji $\mathrm{pH}$ ikan kambingkambing yaitu sebesar $6,46 \pm 0,03$. Hasil $\mathrm{pH}$ ikan kambing-kambing pada penelitian ini tergolong ikan segar karena ambang batas maksimum $\mathrm{pH}$ yang dapat ditoleransi adalah lebih kecil dari 7,0. Kose (2003) melaporkan bahwa ketika $\mathrm{pH}$ ikan diatas 7,0 maka ikan cenderung sudah busuk.

Pengujian total mikroba pada ikan kambing-kambing, didapatkan nilai $6,13 \times 10^{3}$. Hasil ini menunjukkan bahwa total mikroba ikan kambing-kambing lebih rendah dari batas maksimum total mikroba ikan segar standar yaitu 5,0x105 koloni/g (nilai log 5,7 koloni/g) (BSN). Menurut Julianto (2003) kesegaran ikan ditentukan oleh jumlah bakteri yang tidak melebihi $10^{5}(\log \mathrm{TPC}=5)$.

\section{Proporsi lkan Kambing-kambing (C. maculata)}

Proporsi yang digunakan dalam penelitian ini, adalah daging ikan dengan proporsi tertinggi yaitu (39.43\%), sedangkan proporsi terendah pada bagian sirip yaitu (4.22\%). Persentase proporsi ikan kambingkambing dapat dilihat pada Gambar 2.

Proporsi ikan kambing-kambing memiliki nilai yang sejalan dengan penelitian yang dilaporkan oleh Jacoeb et al. (2015) proporsi ikan kakap merah dengan proporsi daging (39\%), tulang (45\%) jeroan (12\%), dan sisik (4\%). Bagian ikan yang dapat dimakan secara umum berkisar antara $45-50 \%$ dari tubuh ikan (Suzuki 1981). Rendemen ikan tergantung pada spesies ikan, spesies ikan 


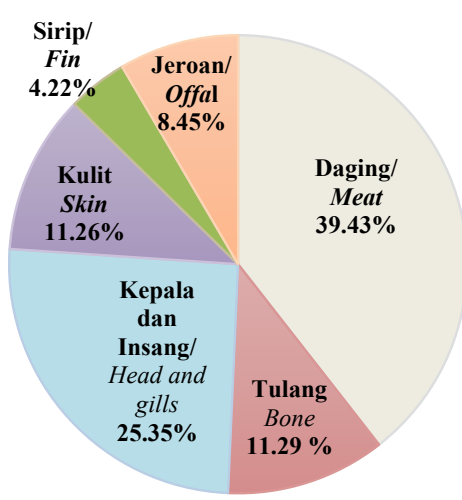

(a)

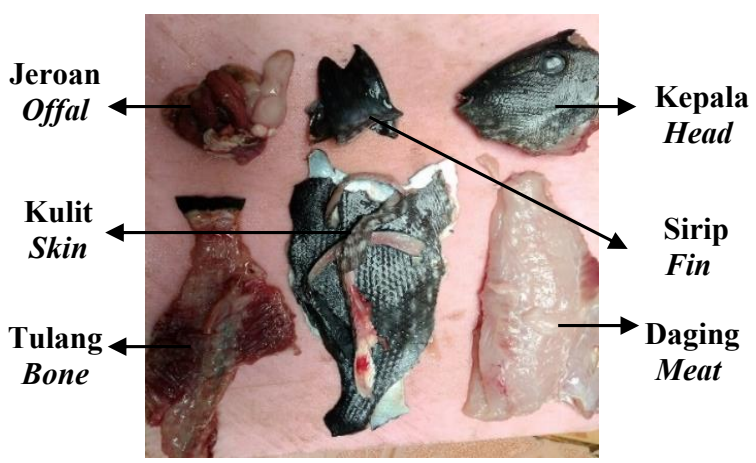

(b)

Gambar 2 Persentase proporsi ikan kambing-kambing (a) proporsi bagian tubuh (b) (Figure 2 Perscentage of C. maculata (a) proportion of body parts (b))

mempengaruhi rasio bagian ikan yang dapat dimakan pada bagian tubuh ikan, bagian terbesar pada tubuh ikan yaitu daging, dengan bagian terbesar yang tidak dapat dimakan yaitu kepala dan jeroan (Olafisoye et al. 2013).

Pembuatan ikan asin kambing-kambing hanya menggunakan daging saja, sedangkan tulang, kepala, kulit, sirip insang dan jeroan menjadi limbah. Limbah ini umumnya dimanfaatkan sebagai bahan baku pembuatan pakan ternak. Hal ini disebabkan oleh ikan kambing-kambing merupakan ikan karang yang berkulit keras sehingga penetrasi garam kedalam daging sulit.

\section{Karakteristik Ikan Asin Kambing- kambing (C. maculata)}

Karakteristik ikan asin kambing-kambing dengan perlakuan konsentrasi garam $5 \%, 10 \%$, $15 \%$ dengan lama penggaraman 12 jam dan 24 jam dapat dilihat pada Tabel 2. Parameter kimiawi dan mikrobiologi ikan asin kambingkambing sudah sesuai dengan standar SNI. 8273:2016. Hasil analisis ragam menunjukkan bahwa penambahan konsentrasi garam yang berbeda berpengaruh nyata terhadap kadar garam dalam daging ikan asin. Akan tetapi lama penggaraman dan interaksi lama penggaman tidak memberikan pengaruh nyata $(\mathrm{P}>0.05)$ terhadap kadar garam dalam ikan asin.

Hasil uji lanjut Duncan menunjukkan bahwa konsentrasi garam 5\% berpengaruh nyata terhadap konsentrasi garam $10 \%$ dan 15. Hal ini menunjukkan bahwa semakin tinggi konsentrasi garam yang digunakan untuk proses penggaraman, maka jumlah kadar garam didalam jaringan ikan juga semakin tinggi. Medina-Vivano et al. (2002) melaporkan bahwa penambahan garam kedalam daging ikan dipengaruhi oleh perbedaan konsentrasi $\mathrm{NaCl}$ awal dengan sel ikan, maka semakin besar kadar garam dalam daging ikan yang dihasilkan.

Kadar garam pada ikan asin yang digunakan dalam penelitian ini berkisar antara $5-15 \%$ dan yang terserap pada tubuh ikan sebesar 3-13\%. Batas asupan maksimal garam bagi manusia $<5 \%$ atau 5 g per hari (WHO 2011). Kadar garam pada ikan asin penelitian ini rerata masih tergolong tinggi. Hasil kadar garam terbaik mendekati satndar adalah pada konsentrasi garam 15\% dan lama penggaraman $24 \mathrm{jam}$.

Hasil analisis ragam menunjukkan bahwa perbedaan konsentrasi garam dan lama panggaraman $12 \mathrm{jam}$ dan 24 jam berpengaruh nyata $(\mathrm{P}<0,05)$ terhadap kadar air dan total mikroba. Hasil uji lanjut Duncan untuk kadar air menunjukkan konsentrasi garam 5\%, 10\% dan lama penggaraman 12 jam berpengaruh nyata terhadap konsentrasi garam 15\% dengan lama waktu penggaraman $24 \mathrm{jam}$. Konsentrasi garam $10 \%$, lama penggaraman 12 jam tidak berbeda nyata dengan semua perlakuan. Konsentrasi garam 5\%, lama penggaraman 24 jam berbeda nyata dan konsentrasi garam 15\% lama penggaraman $24 \mathrm{jam}$. Rerata kadar air ikan kambing-kambing cenderung menurun seiring dengan meningkatnya 
Tabel 2 Karakteristik kimiawi dan mikrobiologi ikan asin kambing-kambing (Table 2 Characteristic of chemical and microbiology salty Spotted oceanic triggerfish)

\begin{tabular}{ccccc}
\hline $\begin{array}{c}\text { Lama penggaraman/ } \\
\text { Duration salting }\end{array}$ & $\begin{array}{c}\text { Konsentrasi } \\
\text { garam/ } \\
\begin{array}{c}\text { Concentration } \\
\text { of salt }(\%)\end{array}\end{array}$ & $\begin{array}{c}\text { Kadar garam / } \\
\text { Salt content } \\
(\%)\end{array}$ & $\begin{array}{c}\text { Kadar air/ Moisture } \\
\text { content }(\%)\end{array}$ & $\begin{array}{c}\text { Total mikroba } \\
\text { Total microbial } \\
(\text { CFU/g) }\end{array}$ \\
\hline & 5 & $3.36 \pm 0.08^{\mathrm{a}}$ & $31.22 \pm 2.73^{\mathrm{c}}$ & $2.79 \times 10^{3 \mathrm{f}}$ \\
12 Jam/ 12 hours & 10 & $7.71 \pm 0.19^{\mathrm{b}}$ & $26.15 \pm 3.61^{\mathrm{abc}}$ & $2.32 \times 10^{3 \mathrm{~d}}$ \\
& 15 & $12.84 \pm 0.23^{\mathrm{c}}$ & $24.09 \pm 2.09^{\mathrm{ab}}$ & $1.86 \times 10^{3 \mathrm{~b}}$ \\
\hline & 5 & $3.76 \pm 0.23^{\mathrm{a}}$ & $27.49 \pm 0.64^{\mathrm{bc}}$ & $2.60 \times 10^{3 \mathrm{e}}$ \\
24 Jam/ 24 hours & 10 & $8.02 \pm 0.24^{\mathrm{b}}$ & $22.04 \pm 3.23^{\mathrm{ab}}$ & $2.23 \times 10^{3 \mathrm{c}}$ \\
\hline Standar/ Standard & 15 & $13.22 \pm 0.11^{\mathrm{c}}$ & $20.32 \pm 0.55^{\mathrm{a}}$ & $1.78 \times 10^{3 \mathrm{a}}$ \\
\hline BSN 2016 & & $12.0-20.0$ & Maks. 40.0 & $1 \times 10^{5}$ \\
\hline
\end{tabular}

kadar garam dan waktu penggaraman yang semakin lama. Hal ini menunjukkan bahwa semakin tinggi konsentrasi garam maka kadar air dalam daging ikan semakin menurun. Paparang (2013) melaporkan bahwa pengaruh konsentrasi garam terhadap kadar air pada daging ikan peda mengalami penurunan dengan bertambahnya konsentrasi garam. Rahmani et al. (2007) melaporkan bahwa semakin lama daging ikan direndam dalam larutan garam maka air yang keluar semakin banyak. Penurunan kadar air juga disebabkan oleh penurunan kelarutan protein pada konsentrasi garam tinggi sehingga protein terpisah sebagai endapan yang menyebabkan menurunnya kemampuan protein mengikat air. Hasil kadar air terbaik mendekati SNI didapatkan pada konsentrasi garam 15\% dan lama penggaraman 24 jam.

Hasil uji lanjut Duncan untuk total mikroba menunjukkan bahwa konsentrasi garam dan lama penggaraman berpengaruh nyata terhadap total mikroba. Konsentrasi garam 5\% berpengaruh nyata dengan konsentrasi garam $10 \%$ dan $15 \%$, pada lama penggaraman 12 jam dan 24 jam, hal ini menunjukkan bahwa semakin tinggi garam yang digunakan dalam proses pembuatan ikan asin maka mikroba akan terhambat. Witono et al. (2013) melaporkan bahwa pengawetan ikan dengan menggunakan garam dapat memecah membran sel mikroba (plasmolysis), karena garam mempunyai tekanan osmosis yang tinggi dan garam dalam daging ikan juga mengurangi jumlah oksigen sehingga pertumbuhan mikroba aerobik terhambat. Hasil total mikroba terbaik mendekati SNI 8273:2016 didapatkan pada konsentrasi garam $15 \%$ dan lama penggaraman 24 jam.

\section{Sensori ikan asin kambing-kambing (C. maculata)}

Hasil uji sensori ikan asin kambingkambing meliputi kenampakan, bau, rasa, tekstur dan jamur pada penelitian ini dapat dilihat pada Gambar 3.

Berdasarkan hasil analisis KruskalWallis $(\mathrm{p}<0.05)$ ikan asin kambingkambing menunjukkan bahwa lama waktu penggaraman tidak memberikan pengaruh nyata terhadap uji kenampakan, bau, rasa, tekstur dan jamur, namun perbedaan konsentrasi garam memberikan pengaruh nyata terhadap uji kenampakan, bau dan tekstur.

Nilai rerata uji sensori pada Gambar 3 untuk parameter kenampakan ikan asin kambing-kambing menunjukkan nilai penerimaan panelis berkisar 6,4-7,5 dengan spesifikasi 7,5 (bersih, cerah spesifik jenis). Hasil anlisis Krussal-Wallis $(\mathrm{P}<0,05)$ untuk uji sensori kenampakan pada ikan asin kambingkambing menunjukkan adanya perbedaan yang nyata konsentrasi garam terhadap kenampakan ikan asin. Hasil lanjut uji Duncan 


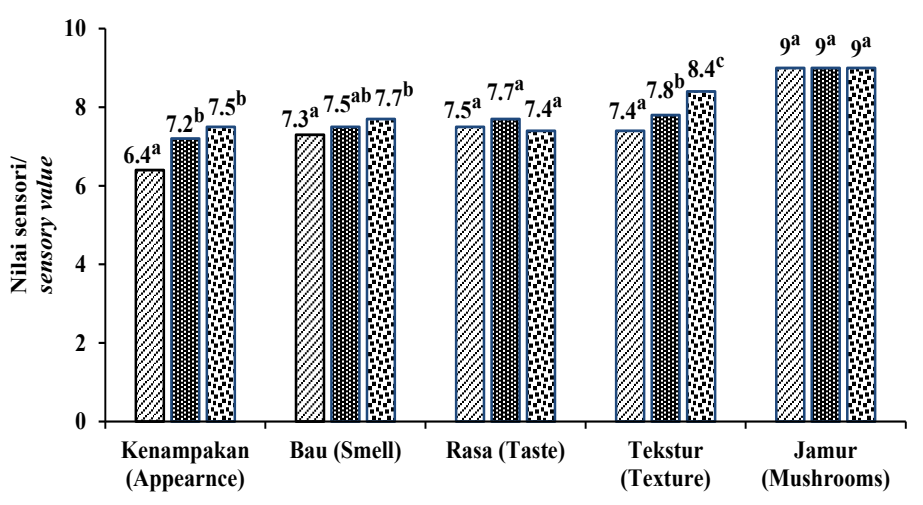

Gambar 3 Nilai sensori ikan asin kambing-kambing dengan kosentrasi garam (5\% $/ / /$,

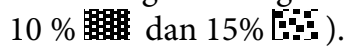

(Figure 3 Sensory value of salty Spotted oceanic triggerfish with salt concentration

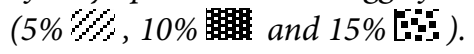

menunjukkan bahwa konsentrasi garam 5\% berbeda nyata terhadap konsentrasi garam $10 \%$, dan $15 \%$, namun konsentrasi garam $10 \%$ tidak memberi perberbedaan nyata dengan konsentrasi garam 15\%. Hal ini menunjukkan bahwa semakin tinggi konsentrasi garam pada ikan asin dapat berpengaruh terhadap kenampakan. Tumbelaka et al. (2013) melaporkan bahwa konsentrasi garam dan lama penggaraman yang semakin tinggi diduga menyebabkan ikan bandeng asin kering terlihat lebih putih karena kristal garam yang terdapat pada permukaan tubuh ikan sehingga tingkat kesukaan panelis berkurang.

Hasil nilai rerata uji sensori pada Gambar 3 untuk parameter bau ikan asin kambingkambing menunjukkan nilai penerimaan penalis berkisar 7,3-7,7 dengan spesifikasi (spesifik jenis bau kurang kuat). Hasil anlaisis Krussal-Wallis $(\mathrm{P}<0,05)$ untuk uji sensori bau pada ikan asin kambing-kambing menunjukkan adanya perbedaan yang nyata antara konsentrasi garam terhadap bau ikan asin. Hasil uji lanjut Duncan pada uji bau menunjukkan bahwa konsentrasi garam 5\% tidak berbeda nyata terhadap garam $10 \%$, konsentrasi $10 \%$ juga tidak berbeda nyata terhadap 15\%, namun konsentrasi garam $5 \%$ berbeda nyata terhadap konsentrasi $15 \%$. Hal ini menunjukan bahwa semakin tinggi konsentrasi garam akan mempengaruhi bau ikan asin. Konsentrasi garam dan lama penggaraman yang semakin tinggi membuat penilaian panelis semakin meningkat (Tumbelaka et al. 2013).

Berdasarkan nilai rerata uji sensori tekstur ikan asin kambing-kambing (Gambar 3) menunjukkan nilai penerimaan penalis berkisar 7,4-8.4. dengan spesifikasi 7,4 (padat kurang kering) dan 8,4 (padat kering). Hasil anlisis Krussal-Wallis $(\mathrm{P}<0,05)$ menunjukkan konsentrasi garam berpengaruh terhadap tekstur ikan asin. Hasil uji lanjut Duncan menyatakan bahwa konsentrasi garam 10\% berbeda nyata dengan konsentrasi garam $5 \%$ dan $15 \%$. Konsentrasi garam yang bertambah mempengaruhi penilaian panelis terhadap tekstur ikan kambing-kambing. Hasil penelitian ini sesuai dengan penelitian Rahmani et al. (2007) tingkat kesukaan panelis terhadap tekstur ikan gabus asin cenderung meningkat dengan meningkatnya konsentrasi garam.

\section{KESIMPULAN}

Konsentrasigaram dan lama penggaraman berpengaruh nyata terhadap karakteristik ikan asin, yang meliputi kadar garam, kadar air, dan total mikroba konsentrasi garam 15\% lama penggaraman 24 jam merupakan perlakuan terbaik dan sesuai dengan persyaratan mutu SNI 8273:2016. 


\section{DAFTAR PUSTAKA}

Ackbarali DS, Maharaj R. 2014. Sensory evaluation as a tool in determining acceptability of innovative products developed by undergraduate students in food science and technology at the University of Trinidad and Tobago. Journal of Curriculum and Teaching. 3(1): 10-27.

Alemu LA, Melese AY, Gulelat DH. 2013. Effect of endogenous factors on proximate composition of nile tilapia (Oreochromis Niloticus L.) fillet from Lake Zeway. American Journal of Research Communication. 1(11): 405-410.

Abraham-Olukayode, AO Adejonuwo, OA Oramadike, CE Kolade, OY. 2012. Proximate composition of $P$. elongatus subjected to different processing techniques. Journal Fish Aquatic Science. 8(1): 282-286.

[AOAC] Association of Official Analytical Chemist. 2005. Official Methods of Analysis. Mayland USA (US): Association of Official Analytical Chemist Inc.

[BKIPM] Badan Karantina Ikan, Pengendalian Mutu dan Keamanan Hasil Perikanan. 2017. Jumlah Data Impor Ikan Asin Kering. Jakrata (ID): Badan Karantina Ikan, Pengendalian Mutu dan Keamanan Hasil Perikanan.

[BSN] Badan Standardisasi Nasional. 2006. SNI 01-2323.3-2006. Cara Uji MikrobilologiBagian 3 Penentuan Angka Lempeng Total (ALT) Pada Produk Perikanan. Jakarta (ID): Badan Standardisasi Nasional.

[BSN] Badan Standardisasi Nasional. 2016. SNI 8273:2016. Ikan Asin Kering. Jakarta (ID): Badan Standardisasi Nasional.

Dempson IB, Schwarz CJ, Shears M, Furey G. 2004. Comparative proximate body composition of atlantic salmon with emphasis on parr from fluvial and lacustrine habitats. Journal of Fish Biology. 64: 1257-1271.

Febrinawati. 2017. Profil cemaran Pb, formaldehid dan mikroba pada ikan asin kepala batu, ikan asap dan terasi di kecamatan Dente Teladas kabupaten Tulang Bawang. Jurnal
Teknologi Industri dan Hasil Pertanian. 22(1): 1-7.

Hardoko, Sasmito BB, Puspitasari YE, Lilyani N. 2018. Konversi ikan asin menjadi nugget berserat pangan dengan tambahan ampas tahu dan beberapa jenis binder. Jurnal Pengolahan Hasil Perikanan Indonesia. 21(1): 54-67.

Junianto. 2003. Teknik Penangkapan Ikan. Jakarta. (ID): Penebar Swadaya

Jacoeb AM, Suptijah P, Kristantina WY. 2015. Komposisi asam lemak, kolesterol, dan deskripsi jaringan fillet kakap merah segar dan goreng. Jurnal Pengolahan Hasil Perikanan Indonesia.16(2): 98-107.

[KKP]. Kementrian Kelautan dan Perikanan. 2015. Statistik Perikanan Tangkap Indonesia. Jakarta (ID): Pusat Data Statistika dan Informasi Kementrian Kelautan dan Perikanan Tahun 2015. (27 Februari 2018).

Kumar PM, Ruba Annathai A, Jeya Shakila R, Shanmugan. 2014. Proximate and majormineral composition of 23 medium sized marine fin fishes landed inthe thoothukudi coast of india. Journal of Nutrition Food Science. 4(1):1-7.

Kose S. 2003. An investigation of quality in anchovy (Engraulis encrasicolus) stored at different temperatures. Turkey Journal Veterinary Animal Science. 28: 575-582.

Medina-Vivanco M, Sobral PJ, do A, Hubinger MD. 2002. Osmotic dehydration of tilapia fillets in limited volume of ternary solutions. Chemical Engineering. 86: 199-205.

Njinkoue JM, Gouado I, Tchoumbougnang F, Ngueguim JH, Ndinteh DT, FomogneFodjo Y, Schwigert FJ. 2016. Proximate composition, mineral content and fatty acid profile of two marine fishes from Cameroonian coast: Pseudotolithus typus (Bleeker, 1863) and Pseudotolithus elongatus (Bowdich, 1825). NFS Journal. 4:27-31.

Nakamura YN, Ando M, Seoka M, Kawasaki KI, Tsukamasa Y. 2007. Changes of proximate and fatty acid compositions of the dorsal and ventral ordinary muscles of the full-cycle cultured Pacific bluefin tuna Thunnus orientalis with the growth. Food Chemistry. 103: 234-24. 
Olafisoye O, Olutona O, Osibote A. 2013. Trace metal, proximate composition and anatomical properties of four fish species commonly consumed in south-western, Nigeria. International Conference on Food and Agricultural Sciences. 55(4): 18-22.

Paparang RW. 2013. Studi pengaruh variasi konsentrasi garam terhadap citrarasa peda ikan layang. Jurnal Media Teknologi Hasil Perikanan. 1(1): 1-4.

Riski K, Fakhrurrazi, Abrar M. 2017. Isolasi bakteri Staphylococcus aureus pada ikan asin talang-talang (Scomberoides commersonnianus) di kecamatan Leupung kabupaten Aceh Besar. Jurnal Ilmiah Mahasiswa Veteriner. 1(3): 366-374.

Riansyah A, Supriadi A, Nopianti R. 2013. Pengaruh perbedaan suhu dan waktu pengeringan terhadap karakteristik ikan asin sepat siam (Trichogaster pectoralis) dengan menggunakan oven. Fishtech. 2(1): 53-68.

Roy BC, Miyake, Ando M, Kawasaki KI,Tsukamasa Y. 2010. Proximate and fatty acid composition in different flesh cuts of cultured, cultured fasted, and wild pacific bluefin tuna (Thunnus orientalis). Journal of Aquatic Food Product Technology. 19: 284-297.

Rahmani Y, Erryana M. 2007. Pengaruh metode penggaraman basah terhadap karakteristik produk ikan asin gabus (Ophiocephalus striatus). Jurnal Teknologi Pertanian. 8(3): 142-152.

Rochima E. 2005. Pengaruh fermentasi garam terhadap karakteristik jambal roti.
Buletin Teknologi Hasil Perikanan. 8(2): 46-56.

Suzuki, Taneko. 1981. Fish and Krill Protein: Processing Technology. London (UK): Applied Science Publishers Ltd.

Tahitu JM. 2014. Pengaruh konsentrasi garam dan waktu perendaman terhadap cita rasa ikan kawalinya (Selar leptolepis) asin kering. Biopendix. 1(1): 65-70.

Tumbelaka RA, Naiu, AS, Dali FA. 2013. Pengaruh konsentrasi garam dan lama penggaraman terhadap nilai hedonik Ikan bandeng (Chanos chanos) Asin Kering. Jurnal Ilmiah Perikanan dan Kelautan. 1(1): 48-54.

Venugoval V. 2008. Seafood Processing; Adding Value Through Quick Freezing Retortable Packaging and Cook Chilling. New York (US): Taylor and Prancis publisher.

Witono, Judy Retti B, YIP, Arry Miryanti, dan Lia Yuniarti. 2013. Studi Kinetika Dehidrasi OsmotikpadaIkan Teri Dalam Larutan Biner dan Terner. Bandung. (ID) :Lembaga Penelitian dan Pengabdian Kepada Masyarakat Universitas Katolik Parahyangan

Winarno FG. 2008. Kimia Pangan dan Gizi. Jakarta (ID): Gramedia Pustaka Utama.

[WHO] World Health Organization. 2011. Diet and Chronic Diseases. Genva (US): World Health Organization

Younis EM, AA Abdel-Warith, Al-Asgah AA, AS El-Shayia. 2011. Chemical composition and mineral of commercial fish species from the arabian gulf coast of saudi arabia. Journal of Animal and Veteranary Advances. 10(23): 3053-3059. 